\title{
Sensorineural Hearing Loss of Suspected Autoimmune Etiology: Two Cases of Cogan's Syndrome
}

\author{
Jungmin Ahn ${ }^{1}$, Brian Kim $^{1}\left(\mathbb{D}\right.$, Kyoung Rai Cho ${ }^{2} \mathbb{D}$, and Young-Soo Chang ${ }^{2}(\mathbb{D}$ \\ ${ }^{1}$ Department of Otorhinolaryngology-Head and Neck Surgery, Korea Cancer Center Hospital, \\ Korea Institute of Radiological and Medical Science, Seoul; and \\ ${ }^{2}$ Department of Otorhinolaryngology-Head and Neck Surgery, Sanggye Paik Hospital, College of Medicine, Inje University, Seoul, Korea
}

\section{자가 면역 병인이 의심되는 감각신경성 난청: Cogan 증후군 2예}

안정민 $^{1} \cdot$ 김브라이언 ${ }^{1} \cdot$ 조경래 ${ }^{2} \cdot$ 장영수 ${ }^{2}$

${ }^{1}$ 한국원자력의학원 원자력병원 이비인후-두경부외과, ${ }^{2}$ 인제대학교 의과대학 상계백병원 이비인후과학교실

\author{
Received May 31, 2021 \\ Revised July 26, 2021 \\ Accepted August 23, 2021 \\ Address for correspondence \\ Young-Soo Chang, MD, PhD \\ Department of Otorhinolaryngology- \\ Head and Neck Surgery, \\ Sanggye Paik Hospital, \\ College of Medicine, Inje University, \\ 1342 Dongil-ro, Nowon-gu, \\ Seoul 01757, Korea \\ Tel $+82-2-950-8815$ \\ Fax $+82-504-365-5377$ \\ E-mail yschang83@gmail.com
}

Cogan's syndrome is a rare inflammatory disease characterized by non-syphilitic keratitis and vestibulo-auditory symptoms including hearing loss, tinnitus, and vertigo. Although its precise pathogenesis is not known, Cogan's syndrome is generally considered an autoimmune disease. This hypothesis is supported by the frequently successful remission of hearing loss after steroid administration and the association with other autoimmune disorders such as rheumatoid arthritis. Medical treatment of Cogan's syndrome depends on disease severity and on how extensive the disease is. The involvement of inner ear pathology requires systemic corticosteroid therapy. In cases of treatment failure or the need for a corticosteroid-sparing effect, other immunosuppressive drugs can be used. We experienced two patients with typical Cogan's syndrome, presenting bilateral progressive sensorineural hearing loss and dizziness with ocular involvement, which we have successfully treated with systemic steroid administration and immunosuppressive therapy.

Korean J Otorhinolaryngol-Head Neck Surg 2021;64(12):943-8

Keywords Autoimmune diseases; Cogan syndrome; Dizziness; Hearing loss.

\section{서 론}

Cogan 증후군은 비매독성 간질각막염(non-syphilitic interstitial keratitis)과 전정 및 청각 증상을 특징으로 하는 원 인을 알 수 없는 만성 염증성 질환이다. ${ }^{1)}$ 1945년 David G. Cogan이라는 안과 의사에 의해 처음 기술된 이후 국외에서 는 100예 이상이 보고되고 있어, Cogan 증후군의 임상 증상 및 특징, 그리고 예후에 대한 정보가 알려지고 있다. 전형적인 유형은 양안의 주변부 각막의 상피하 각막염으로 시작되어 간질각막염으로 발전하며, 전정 및 청각 증상은 메니에르병

This is an Open Access article distributed under the terms of the Creative Commons Attribution Non-Commercial License (https://creativecommons.org/licenses/by-nc/4.0) which permits unrestricted non-commercial use, distribution, and reproduction in any medium, provided the original work is properly cited.
증상과 유사한 어지럼, 감각신경성 난청을 보이게 된다. ${ }^{2}$ 이 외에 관절염, 림프절 종대, 대동맥염 등 다양한 전신 질환이 동반될 수 있다. ${ }^{3}$

청력손실은 일반적으로 양측성 및 진행성이며, $37 \%-67 \%$ 의 환자에서는 전농으로 진행되기도 한다.,5) 병리조직 연구에 서 림프구(lymphocyte)와 형질세포(plasma cell)가 와우의 spiral ligament에 침투하는 특징이 확인되어, 내이에 대한 자가면역 항체의 형성이 전정 및 청각증상을 유발하는 것으 로 추정되고 있다. ${ }^{6)} \operatorname{Cogan}$ 증후군은 국내에서 5예 정도만 보 고될 정도로 드문 질환으로, 본 저자들은 안증상과 함께 양 측성 청력저하와 어지럼을 주소로 내원하여, 고용량 스테로 이드 및 면역억제제를 사용하여 치료하였기에 문헌 고찰과 함께 보고하는 바이다. 


\section{증 례}

증례 1

27세 여자가 양측 청력저하, 회전성 어지럼 및 양안의 충혈 로 내원하였다. 내원 1주일 전부터 전신 무력감 및 근육통이 있었으며, 당시부터 우측의 청력저하 및 이충만감, 그리고 어 지럼 증상이 시작되었다. 전신 근육통 및 어지럼은 점차 호전
되었으나, 좌측의 난청이 발생하는 등 청각 증상은 점차 심해 졌다. 과거력과 가족력상 특이사항은 없었고, 내원 시 생체 징후는 정상이었다. 이학적 검사상 고막 소견은 정상이었고, 신체 검사에서 양측 안구의 경한 결막 충혈이 보였다. 내원 당일 시행한 순음청력검사에서는 경도의 양측 감각신경성 난 청 소견이 확인되었다(Fig. 1A). 신경학적 검사에서 좌측으로 향하는 자발안진이 관찰되었고, 좌측을 볼 때는 증가하며,
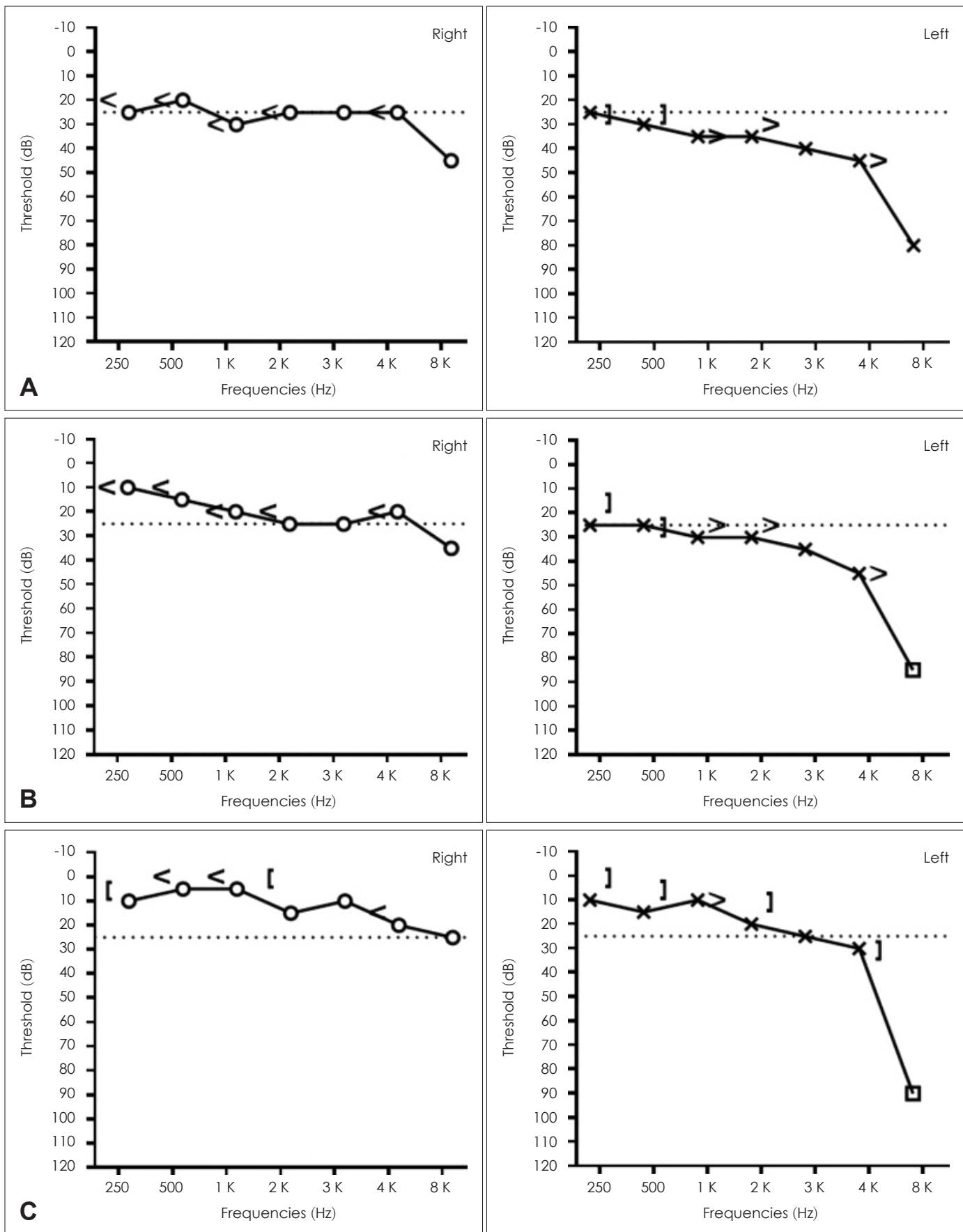

Fig. 1. Flow of pure-tone audiogram of case 1. Pure-tone audiogram on initial presentation (A), audiogram a week of steroid therapy (B), and audiogram after 3 weeks of steroid administration (C). 
반대측을 쳐다볼 때는 감소하는 Alexander 법칙을 따르고 있었다. 시선 고정을 제거하였을 때 자발안진이 증강되었지 만, 두진 및 체위변환 검사에 의한 자발안진의 변화는 없었 다. 두부충동검사에서 우측으로 고개 회전 시 교정성 단속운 동이 관찰되었고, finger-to-nose test, heal-to-shin test, 급속회외회내운동(rapid alternating movement), 롬버그검 사(Romberg test), 그리고 일직선 보행(tandem gait)을 포함 하는 소뇌기능검사는 모두 정상이었다.

환자는 입원하여 일주일간 하루 $10 \mathrm{mg}$ 의 dexamethasone 정맥 투여와 함께 혈청학적 검사, 온도안진검사, 측두골 전산 화단층촬영 및 자기공명영상(MRI) 등의 추가 검사를 시행 하였다. 헐청학적 검사상 매독혈청검사는 음성이었고, 적혈구 침강속도는 $120 \mathrm{~mm} / \mathrm{hr}, \mathrm{C}$-반응단백은 $11.28 \mathrm{mg} / \mathrm{dL}$ 로 상승 되어 있었다. 자가면역 항체검사에서 류마티스인자(rheumatoid factor), 혈청 항중성구세포질항체(antineutrophil cytoplasmic antibody) 및 항핵항체(antinuclear antibody)에서 양성 반응을 보였고, 보체 C3과 $\mathrm{C} 4$ 수치는 정상 범위보다 높 았다. 입원치료 3 일째 시행한 온도안진검사에서 우측 반규관 의 $52 \%$ 마비 소견을 보였고, 자발안진은 나타나지 않았다. 또 한, 측두골 전산화단층촬영에서 해부학적 이상은 없었으며, 자기공명영상에서 내이수종 및 후미로성 병변 등 특이소견은 없었다.

입원 1 일째, 양안 충혈은 점차 호전 양상이었으나 시야 혼 탁을 호소하여 안과적 검진을 시행하였다. 교정시력이 양측 에서 1.0 이었고, 안압은 정상이었다. 양안에서 결막 충혈(injection)이 관찰되었고, 세극등 현미경 검사에서 양안의 포도 막염(uveitis)이 보였다. 이에 스테로이드 안약을 2시간 간격 으로, 조절마비제 안약을 12 시간 간격으로 사용하기 시작하 였다.

환자는 스테로이드 투여 후 양안의 결막 충혈 및 시야 혼탁,
어지럼 및 청력저하는 서서히 호전되었다(Fig. 1B). 치료 8일 째부터 퇴원하여 4일에 걸쳐 스테로이드 감량을 진행하였으 며 이후 2주 동안 methylprednisolone $4 \mathrm{mg} /$ day로 저용량 으로 지속하였다. 퇴원 2주 후에는 주관적 증상이 모두 호전 되고, 청력 역치 또한 정상 범주로 회복되어(Fig. 1C) 스테로 이드 치료를 중단하였으며, 혈액검사상 적혈구침강속도는 50 $\mathrm{mm} / \mathrm{hr}, \mathrm{C}$-반응단백은 $0.33 \mathrm{mg} / \mathrm{dL}$ 로 호전되었다. 안과적 검 사상에서는 포도막염이 아직 남아있는 상태로 점안액을 유 지하고 있으며, 증상 첫 발현 후 3 개월이 지난 현재까지는 추 가적인 난청 및 어지럼 발생 없이 경과 관찰 중에 있다.

\section{증례 2}

50세 여자가 전신 관절통 및 시야 혼탁을 주소로 응급실에 내원하였다. 고혈압 이외에 특이병력 없는 환자로, 5 일 전 등 산 이후 상기 증상이 점차 악화되어 내원하였다. 응급실에서 시행한 혈액검사상 백혈구 $12330 / \mathrm{uL}$, 혈소판 115000/uL, 혈 액요소질소 $26.3 \mathrm{mg} / \mathrm{d}$, 크레아틴 $1.66 \mathrm{mg} / \mathrm{dL}$ 소견 관찰되어, 탈수에 의한 신전성 급성 신손상(prerenal type acute renal failure)으로 진단되어 입원 후 수액 공급 시행하였다. 이후 신기능은 정상으로 회복되었으며 염증 수치 모두 호전되었으 나 시야 혼탁 증상은 점차 악화되고, 입원 3일째 급작스럽게 발생한 안구 통증과 양측 청력저하 및 이명 호소하여 안과 및 이비인후과 진료를 진행하였다.

안과 검진상 양측 안압 증가, 전방 염증(anterior ocular inflammation) 및 안저 혈관염(Roth's spot) 소견 관찰되어 범 포도막염(panuveitis) 및 개방각 녹내장(open angle glauco$\mathrm{ma}$ ) 진단하였다(Fig. 2).

이비인후과 문진상 양측 청력저하, 이명 및 어지럼을 호소 하였다. 이학적 검사상 양측 외이도 및 고막은 정상 소견이었 으며, 순음청력검사에서 우측 $55 \mathrm{~dB}$, 좌측 $60 \mathrm{~dB}$ 의 감각신경
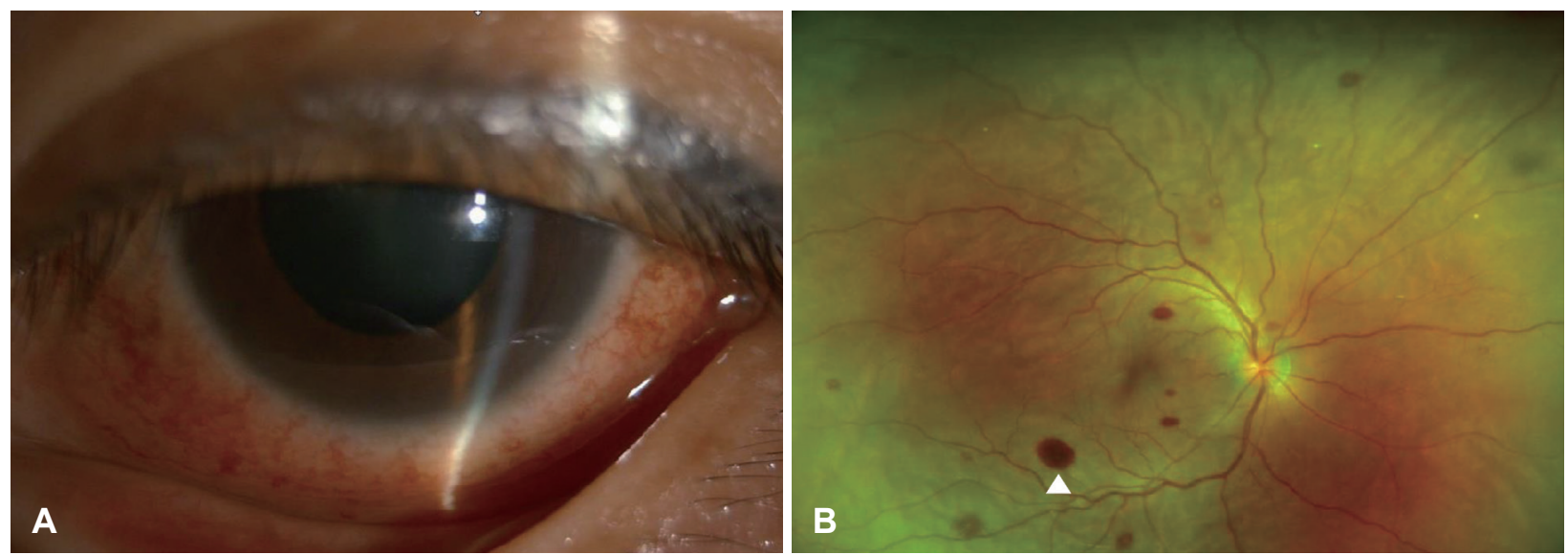

Fig. 2. Images of the anterior segment $(A)$ and fundus $(B)$ of case 2. Non-infectious uveitis, showing diffuse episcleral hyperemia (A) and fundus, showing several Roth's spots (arrowhead) (B). 


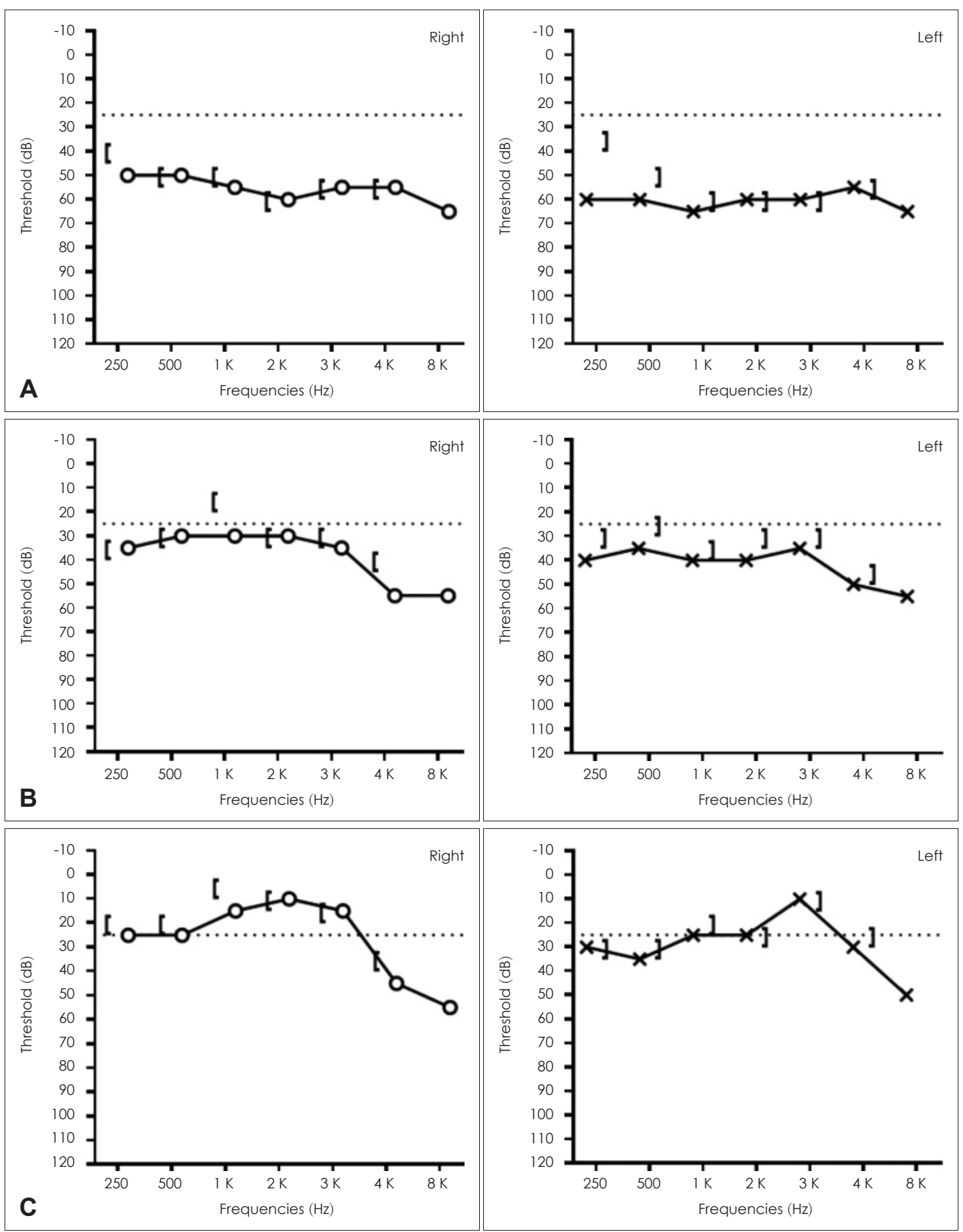

Fig. 3. Flow of pure-tone audiogram of case 2. Pure-tone audiogram on initial presentation of hearing loss (A), audiogram after steroid therapy of about 10 days $(B)$, and audiogram after 2 weeks of steroid and immunosuppressive therapy (C).

성 난청소견을 보였다(Fig. 3A). 비디오안진검사상 자발안진 및 자세 변화 시 안진은 관찰되지 않았으며, 비디오 두부충 동검사에서도 특이소견은 관찰되지 않았다.

범포도막염 및 양측 중등도 감각신경성 난청이 동발된 것 을 고려하여 자가면역 항체 검사 및 혈청검사, 두부 전산화단 층촬영을 진행하였으며, 매독혈청검사를 포함하여 모두 음성 이었다. Cogan 증후군 진단하에 고용량 스테로이드 약물치료 (methylprednisolone $125 \mathrm{mg} / \mathrm{day}$ )를 시작하였다. 스테로이드 약물치료 및 안압 조절을 위한 마니톨(mannitol) 투여에도 안압 증가 호전되지 않아 Ahmed valve operation 시행하여 안압 조절을 시행하였다.

고용량 스테로이드 약물치료 시작하고 5일 경과 후 시행한 순음청력검사상 우측 $49 \mathrm{~dB}$, 좌측 $51 \mathrm{~dB}$ 소견이었으며, 어음 검사상 최대명료도치는 우측 $44 \%$, 좌측 $52 \%$ 소견을 보였다. 
7일간 methylprednisolone $125 \mathrm{mg} /$ day 사용 후 안압 및 어 지럼 증상이 호전되었으며, 순음청력검사상 우측 $36 \mathrm{~dB}$, 좌측 $41 \mathrm{~dB}$, 어음명료도 우측 80\%, 좌측 68\%로 호전되어(Fig. 3B) prednisolone $45 \mathrm{mg} / \mathrm{day}$ 로 변경하였다. 그러나 다시 안구 전 방 염증 소견 악화되어 methylprednisolone $1000 \mathrm{mg} / \mathrm{day}$ 로 증량하여 펄스요법을 3일간 진행하였다. 이후 prednisolone $60 \mathrm{mg} /$ day 5일, 45mg/day 14일간 사용 및 azathioprine 100 $\mathrm{mg}$ 을 투여하였다. 난청 발생 후 1 개월째 시행한 순음청력검 사에서 우측 $16 \mathrm{~dB}$, 좌측 $23 \mathrm{~dB}$, 어음명료도 우측 $92 \%$, 좌측 $88 \%$ 로 관찰되었으며(Fig. 3C), 이후 azathioprine 투여 유지 하고 있다. 증상 첫 발현 후 5 개월째 청력의 악화나 어지럼 발 생은 없으며 간헐적으로 안압이 증가하여 이비인후과, 안과 및 내과 추적 관찰 중이다.

\section{고 찰}

Cogan 증후군은 비매독성 간질각막염과 전정 및 청각 기 능 저하를 특징으로 하는 드문 염증성 질환이다. 전정 및 청 각 증상은 메니에르병과 흡사하게 현훈, 이명, 청력저하 등의 증상으로 나타나며 안증상의 이전 혹은 이후에 발생할 수 있 으며, 그 사이 간격은 보통 2년 이내이다. 각막염 없이 눈의 염 증이 동반된 경우, 혹은 전정 및 청각 증상과 눈의 염증 사이 간격이 2년을 초과하는 경우는 비전형적 Cogan 증후군으로 분류한다. 주로 젊은 성인(20-40대)에서 많이 발생하고 성별 에 따른 유병률의 차이는 없다.5) 현재까지 밝혀진 바에 의하 면, Cogan 증후군은 자가면역성 질환으로써 눈과 전정 및 청 각 증상 외에도 환자의 대부분에서 발열, 관절염 등 다양한 전신 증상이 동반될 수 있다.

자가면역성 내이질환(autoimmune inner ear disease, AIED) 은 전체 난청 환자 중 $1 \%$ 미만을 차지하는 드문 질환으로.) 현재까지 AIED에 대하여 밝혀진 특이항체가 없어 이 질환 을 진단하는 것은 쉽지 않은 일이다. 특히 다른 자가면역성 질 환을 동반하고 있지 않은 경우에는 더욱 진단이 어려우며, 메 니에르병과 유사한 양상의 증상으로 두 질환 사이의 감별이 어렵다. Pagnini 등은 33 명의 소아 Cogan 증후군 환자를 대상으로 Cogan 증후군의 임상양상을 보고한 바 있다. 소아 Cogan 증후군의 임상양상은 성인과 다르지 않으며, 임상적 증상 중 예후와 연관성을 보이는 것은 없었으나, 증상 발현과 치료 시작의 간격이 2 개월 이내인 경우에서 그 이상인 경우 보다 완전 관해율이 높아 오직 조기 진단과 치료만이 좋은 예 후를 예측할 수 있는 유일한 인자로 확인되었다. 따라서 환자 가 양측의 진행성 감각신경성 난청을 보이는 경우에는 자가면 역성 내이질환을 반드시 고려하고 면역학적검사 및 다른 자
가면역성 질환의 동반 여부를 확인해야 할 것이다.

Cogan 증후군의 치료는 질환의 임상양상에 따라 결정된다. 안증상에 국한된 경우에는 국소적 스테로이드 점안액을 이용 하여 치료할 수 있으며, 간질각막염인 경우 $1 \%$ prednisolone acetate와 mydriatic eye drop을 이용하여 눈부심 증상을 완화시켜주며 유착을 방지할 수 있다. ${ }^{9)}$ 그러나 광범위한 안 증상이 전정 및 청각 증상이나 전신적인 혈관염과 동반된 경 우에는 전신 스테로이드 치료를 시행한다.

전정 및 청각 증상의 치료는 전신 스테로이드 사용으로, 초 기 치료로는 prednisolone $1-2 \mathrm{mg} / \mathrm{kg} / \mathrm{day}$ 를 고려할 수 있으 며, 임상 양상이 호전되면 용량을 감량한다. 2-3주 가량의 고 용량 스테로이드 치료로 순음청력검사상 청력의 호전이 관찰 되면, 4-8주에 걸쳐 감량하게 된다.10) 추가적으로 고실 내 스 테로이드 주입술을 고려해볼 수 있으며, 아직까지 이에 대한 근거는 부족하나, 안전한 2차 치료 방법으로 사용될 수 있 다. ${ }^{11)}$ 스테로이드 감량 시 반복적인 난청이 관찰될 경우에는 cyclophosphamide, methotrexate, azathioprine, tacrolimus, mycophenolate mofetil, tumor necrosis factor inhibitor 등의 면역억제제 치료를 고려할 수 있다. ${ }^{10)}$ 이러한 치료에도 고도-심도 난청으로 진행한 경우 인공와우이식술을 시행할 수 있으며, 인공와우이식술 후 경과는 비자가면역성 난청의 예후와 유사한 것으로 보고되었다. ${ }^{12)}$

Cogan 증후군의 전형적인 예후는 반복적인 안증상과 전정 및 청각 증상의 재발로, Mayo 클리닉에서 보고한 바에 의하 면 52\%에서 양측 전농, $18 \%$ 에서 일측 전농으로 진행하였다 고 보고하였다. ${ }^{13)} \operatorname{Cogan}$ 증후군의 예후는 적극적인 면역억제 제 치료를 통하여 향상시킬 수 있는 것으로 보고되고 있으며, 초기 치료로 고용량 스테로이드 치료 후 infliximab을 이용 한 면역억제제 치료를 시행한 한 연구에서 기존의 문헌에서 보고된 5-10년 내 $31 \%$ 의 재발률을 $13 \%$ 로 낮추었다고 보고 하였다. ${ }^{14)}$

전정 및 청각 증상이 전형적 Cogan 증후군의 임상양상임 에도 불구하고 국내에서는 주로 안과나 류마티스 내과 등에 서 일부 보고되어 있다. 아직까지 혈청학적 검사를 통한 진단 은 제한적인 상태이며 임상양상 및 배제진단을 통하여 $\mathrm{Co}^{-}$ gan 증후군을 진단할 수 있으나, 이비인후과 영역에서의 전정 및 청각학적 검사로는 Cogan 증후군과 다른 자가면역 질환 을 감별하기 어렵다. 돌발성 또는 진행성 양측 감각신경성 난 청과 함께 안증상을 호소할 경우, 감각신경성 난청에 대한 적 극적인 검사를 통하여 다른 원인질환을 배제하고, 안과적 진 찰을 통하여 간질각막염에 대한 평가가 필요하다. 간질각막 염은 매독성 간질각막염과 자가면역성 간질각막염이 그 원인 질환으로 알려져 있기 때문에, 전정 및 청각 증상을 동반한 
비매독성 간질각막염의 진단은 전형적 Cogan 증후군의 진 단에 도움이 될 수 있으며, 녹내장, 결막염 또는 포도막염과 같은 비전형적 Cogan 증후군의 안증상이 나타날 수 있음을 유념해야 한다. ${ }^{15)}$ 또한 Cogan 증후군에서 어지럼은 내림프수 종으로 인하여 메니에르병과 유사한 전정기능 장애가 발생하 는 것으로 이해되고 있으나, 본 증례에서와 같이 동반된 안과 질환에 의해서도 발생할 수 있음을 고려해야 한다. 증례 2 환 자는 안압 상승 시 비회전성 어지럼을 보였으며, 전정기능 검 사상 특이소견은 관찰되지 않았고, 어지럼은 안압의 변화에 따라 완화와 악화를 반복하였다. 따라서, 시야 혼탁과 안압 증가와 같은 안증상 또한 어지럼과 연관성을 가질 수 있으므 로 어지럼 호소 시 전정기능평가와 안과적 검사를 통하여 어 지럼의 원인에 맞는 적절한 치료가 필요하다.

양측성의 진행성 또는 돌발성 감각신경성 난청을 호소하는 환자에서는 안증상의 확인 및 안과적 진찰, 그리고 면역반응 의 전신 침범 여부에 대한 적극적인 평가를 통하여 Cogan 증 후군을 조기 진단하고, 적절한 치료를 통하여 영구적인 청력 소실 및 안증상의 재발을 예방할 수 있을 것으로 사료되어, 이를 문헌 고찰과 함께 보고하는 바이다.

\section{Acknowledgments}

None.

\section{Author Contribution}

Conceptualization: Jungmin Ahn, Young-Soo Chang. Formal analysis: Young-Soo Chang. Resources: Jungmin Ahn. Supervision: Young-Soo Chang. Visualization: Brian Kim. Writing - original draft: Jungmin Ahn. Writing - review \& editing: Jungmin Ahn, Kyoung Rai Cho, Young-Soo Chang.

\section{ORCIDs}

Young-Soo Chang Jungmin Ahn Brian Kim Kyoung Rai Cho https://orcid.org/0000-0003-4491-5088

https://orcid.org/0000-0003-2029-6243

https://orcid.org/0000-0002-0933-079X

https://orcid.org/0000-0001-9633-8281

\section{REFERENCES}

1) Cogan DG. Syndrome of nonsyphilitic interstitial keratitis and vestibuloauditory symptoms. Arch Ophthalmol 1945;33(2):144-9.

2) Son HJ, Ulualp SO. Course of auditory impairment in Cogan's syndrome. Am J Otolaryngol 2009;30(1):65-8.

3) Bovo R, Ciorba A, Trevisi P, Aimoni C, Cappiello L, Castiglione A, et al. Cochlear implant in Cogan syndrome. Acta Otolaryngol 2011;131(5):494-7.

4) McDonald TJ, Vollertsen RS, Younge BR. Cogan's syndrome: Audiovestibular involvement and prognosis in 18 patients. Laryngoscope 1985;95(6):650-4.

5) Grasland A, Pouchot J, Hachulla E, Blétry O, Papo T, Vinceneux P. Typical and atypical Cogan's syndrome: 32 cases and review of the literature. Rheumatology (Oxford) 2004;43(8):1007-15.

6) Schuknecht HF, Nadol JB Jr. Temporal bone pathology in a case of Cogan's syndrome. Laryngoscope 1994;104(9):1135-42.

7) Kim HJ, Choi YG, Kim HJ, Kim KS. Autoimmune inner ear disease mimicking bilateral Ménière's disease: A case report. Res Vestib Sci 2018;17(1):28-35.

8) Pagnini I, Zannin ME, Vittadello F, Sari M, Simonini G, Cimaz R, et al. Clinical features and outcome of Cogan syndrome. J Pediatr 2012;160(2):303-7.e1.

9) McCallum RM, Haynes BF. Cogan's syndrome. In: Pepose JS, Holland GN, Wilhelmus KR, editors. Ocular Infection \& Immunity. 1st ed. St. Louis: Mosby;1996. p.446.

10) St Clair EW, McCallum RM. Cogan's syndrome. Curr Opin Rheumatol 1999;11(1):47-52.

11) Sakano H, Harris JP. Emerging options in immune-mediated hearing loss. Laryngoscope Investig Otolaryngol 2018;4(1):102-8.

12) Wang JR, Yuen HW, Shipp DB, Stewart S, Lin VY, Chen JM, et al. Cochlear implantation in patients with autoimmune inner ear disease including cogan syndrome: A comparison with age- and sexmatched controls. Laryngoscope 2010;120(12):2478-83.

13) Gluth MB, Baratz KH, Matteson EL, Driscoll CL. Cogan syndrome: A retrospective review of 60 patients throughout a half century. Mayo Clin Proc 2006;81(4):483-8.

14) Durtette C, Hachulla E, Resche-Rigon M, Papo T, Zénone T, Lioger B, et al. Cogan syndrome: Characteristics, outcome and treatment in a French nationwide retrospective study and literature review. Autoimmun Rev 2017;16(12):1219-23.

15) Shamriz O, Tal Y, Gross M. Autoimmune inner ear disease: Immune biomarkers, audiovestibular aspects, and therapeutic modalities of Cogan’s syndrome. J Immunol Res 2018;2018:1498640. 